\title{
Review of Recent Advances in Understanding the Role of Vitamin D in Reducing Cancer Risk: Breast, Colorectal, Prostate, and Overall Cancer
}

\author{
WILLIAM B. GRANT
}

\author{
Sunlight, Nutrition, and Health Research Center, San Francisco, CA, U.S.A.
}

\begin{abstract}
This article is a narrative review of recent epidemiological findings regarding ultraviolet- $B(U V B)$ dose or exposure, serum 25-hydroxyvitamin $D$ [25(OH)D] concentrations, vitamin $D$ supplementation, and genetic variations in $25(\mathrm{OH}) \mathrm{D}$ concentration for incidence, survival, and mortality rates of overall and breast, colorectal, and prostate cancer. According to ecological studies, solar UVB doses are inversely correlated with incidence/mortality rates for about 20 cancer types. Observational studies support a role of higher $25(\mathrm{OH}) \mathrm{D}$ concentrations in reducing risk of breast and colorectal cancer incidence and mortality rates but, for prostate cancer, in increasing incidence rates while reducing mortality rates. Mendelian randomization studies offer little support for vitamin D in reducing cancer risk. Their primary limitation is that they only investigate small variations in genetically predicted $25(\mathrm{OH}) \mathrm{D}$ concentration near the population mean value. The secondary analyses from the VITAL clinical trial indicated significant reductions from $2000 \mathrm{IU} / \mathrm{d}$ of vitamin $\mathrm{D}_{3}$ supplementation in all-cancer incidence and mortality rates for selected subgroups. Thus, Hill's criteria for causality in a biological system are now largely satisfied for supporting the claim that vitamin $D$ reduces the risk of cancer incidence and death.
\end{abstract}

The ultraviolet-B (UVB)-vitamin D-cancer hypothesis was proposed approximately 40 years ago (1). As of August 25,

This article is freely accessible online.

Correspondence to: William B. Grant, Ph.D., Director, Sunlight, Nutrition, and Health Research Center, P.O. Box 641603, San Francisco, CA 94164-1603, USA. E-mail: wbgrant@infionline.net

Key Words: Breast, cancer, colon, colorectal, ecological, Mendelian randomization, prostate, ultraviolet $\mathrm{B}, \mathrm{UVB}, 25$-hydroxyvitamin $\mathrm{D}$, review.
2019, 25,105 publications were listed at PubMed.gov with "cancer" and "vitamin D" or "vitamin $\mathrm{D}_{3}$ " or "25hydroxyvitamin D" or "25-hydroxyvitamin $\mathrm{D}_{3}$ " in the title or abstract. Thus, one might expect that the hypothesis would be widely accepted and included in clinical practice. Unfortunately, that is not the case.

Researchers use several types of evidence to examine the role of UVB irradiance and vitamin D in the risk of cancer incidence, progression, and mortality. The types of evidence include geographical ecological studies; observational studies related to UVB radiation, oral vitamin D intake, and serum 25hydroxyvitamin D [25(OH)D] concentrations; randomized controlled trials (RCTs) of vitamin D supplementation; studies of genetic allele polymorphisms affecting 25(OH)D concentrations; and mechanisms. Each type has strengths and limitations. Thus, all types of studies should be considered when assessing how UVB exposure and vitamin D affect cancer risk.

This article is a narrative review of the evidence supporting the hypothesis, with suggestions on how the evidence can be strengthened.

A literature search was conducted at https://www.ncbi.nlm. nih.gov/pubmed/ and https://scholar.google.com/ by using search terms "cancer", "ultraviolet", "vitamin D", "25hydroxyvitamin D", "ecological", "case-control", "breast", "colorectal", "prostate", and "Mendelian randomization".

\section{Ecological Studies}

Ecological studies treat populations in geographically defined regions as entities and use statistical methods to compare disease outcomes averaged for each region, with risk-modifying factors also averaged for each region. For cancer, incidence or mortality rates are compared with indices for vitamin $\mathrm{D}$ production that can be annual solar radiation dose (1), summertime UVB dose $(2,3)$, or latitude in countries with flat terrain (4). Because many factors affect cancer risk, values for other risk-modifying factors should 
also be used. An ecological study of cancer mortality rates for White people in the United States included indices for alcohol consumption, Hispanic heritage, socioeconomic status (poverty), smoking (lung cancer mortality rates), and urban/rural residence (3). Lung cancer mortality rates integrate decades of the adverse effects of smoking and so are better indices than recent smoking rates. However, they also are affected by diet, with meat consumption an important risk factor (5). Ecological studies are best performed in single midlatitude countries with large UVB dose gradients as well as relatively homogeneous populations or data for the various ethnic groups. A summary of singlecountry ecological studies of UVB and cancer mortality rates is presented in (6). Lower UVB dose has been linked to about 20 cancers. Unfortunately, ecological studies of cancer risk are becoming much harder to conduct because of rising rates of obesity, reduced UVB exposure owing to concerns about skin cancer and melanoma, and improved cancer treatment. For example, U.S. breast cancer mortality rates have shown little geographic variation since the 1990s (7).

It was noted that prostate cancer mortality rates have a different geographical distribution in the United States than most types of cancer for which UVB exposure is associated with reduced risk. Prostate cancer rates are highest in the northwest and lowest in the southeast (8). After Tuohimaa et al. reported a U-shaped relationship between baseline 25(OH)D concentration and prostate cancer incidence (9), I pointed that difference out and suggested it supported their finding (10). More recently, a study in Australia reported that high sun exposure was associated with increased prostate cancer incidence (11). The reason for the increased risk will be discussed here later.

Breast cancer mortality rates exhibited geographic variations with respect to U.S. solar UVB doses for 1950-69 and 1970-94 in a manner similar to that for colon and rectal cancer $(2,3,8)$. However, breast and rectal cancer mortality rates for white males and females near the West Coast were slightly higher in California and Nevada than for most other western states, which was not the case for colon cancer for White males and females. Breast and rectal cancer protection may require higher $25(\mathrm{OH}) \mathrm{D}$ concentration than colon cancer.

\section{Prospective Observational Studies of Cancer Incidence Related to Serum 25(OH)D Concentration}

The more common approach to testing the UVB-vitamin Dcancer hypothesis is to enroll people in a cohort study; measure various parameters, including serum 25(OH)D concentration; and monitor participants for several years. Such prospective studies strongly support the role of vitamin $\mathrm{D}$ in reducing risk of colorectal and lung cancer (Table I).
However, they offer little support for vitamin D's role in reducing risk of breast cancer (Table II). The reasons for the difference are that $25(\mathrm{OH}) \mathrm{D}$ concentrations vary with time and that breast cancer can develop rapidly. Mammography is recommended every 1-2 years, in contrast to sigmoidoscopy or colonoscopy for colorectal cancer screening, which is recommended every 10 years. A review of the welldocumented seasonal variation of breast cancer incidence (higher in spring and fall) suggested that vitamin D protected against breast cancer in summer and that melatonin did so in winter (12). The longer the follow-up time, the lower the odds ratio of cancer versus $25(\mathrm{OH}) \mathrm{D}$ concentration that will be found for breast and colorectal cancer (13) and for allcause mortality rate (14).

On the basis of the shortcomings of prospective studies for $25(\mathrm{OH}) \mathrm{D}$ and breast cancer, it was proposed that casecontrol studies of $25(\mathrm{OH}) \mathrm{D}$ concentration near time of diagnosis be used to evaluate the role of vitamin D in reducing breast cancer risk (22). When findings of breast cancer odds ratio versus $25(\mathrm{OH}) \mathrm{D}$ concentration from 11 studies from seven countries are plotted over each other, the data points overlap well and show a power-law fit (13, 16). The results agree well with those from an observational study using pooled data from two vitamin D clinical trials and one open-label observational study in which serum $25(\mathrm{OH}) \mathrm{D}$ concentration was measured every 6 months (21).

The use of case-control studies to evaluate the role of vitamin $\mathrm{D}$ in reducing cancer risk has been criticized on the basis that having cancer may affect the serum $25(\mathrm{OH}) \mathrm{D}$ concentration. A study involving children aged 2-35 months living in Nepal reported that $25(\mathrm{OH}) \mathrm{D}$ concentration during the acute phase of pneumonia and after recovery did not change significantly, remaining near $32 \mathrm{ng} / \mathrm{ml}$ (23). A study of 374 breast cancer patients in Korea indicated that median serum 25(OH)D concentration changed from 12.9 to $10.5 \mathrm{ng} / \mathrm{ml}$ after neoadjuvant chemotherapy (24). Other studies cited in that article did not report significant changes in $25(\mathrm{OH}) \mathrm{D}$ with neoadjuvant chemotherapy with pathologic complete response. More importantly, in a study of newly diagnosed patients with colorectal cancer in the San Francisco Bay Area with a median 25(OH)D concentration of $27.0 \mathrm{ng} / \mathrm{ml}$ at baseline, researchers found that for patients who did not receive vitamin D supplementation during chemotherapy, the median change from baseline to 6 months was $-0.7 \mathrm{ng} / \mathrm{ml}(-19.4$ to 51.7$)$ for the 58 patients treated with chemotherapy and $1.6 \mathrm{ng} / \mathrm{ml}$ (-6.4 to 33.2) for the 19 patients who did not receive chemotherapy (25). Thus, the assumption that undiagnosed cancer affects serum $25(\mathrm{OH}) \mathrm{D}$ concentration seems invalid which supports the use of case-control studies in determining the $25(\mathrm{OH}) \mathrm{D}$ concentration-cancer incidence relationship for cancer. 
Table I. Cancer incidence related to serum 25-hydroxyvitamin D [25(OH)D] concentration according to meta-analyses.

\begin{tabular}{|c|c|c|c|c|c|c|}
\hline Cancer type & $\begin{array}{l}\text { Number of } \\
\text { studies }\end{array}$ & Conditions & $\begin{array}{l}\text { Number of } \\
\text { participants }\end{array}$ & $\begin{array}{c}25(\mathrm{OH}) \mathrm{D} \\
(\mathrm{ng} / \mathrm{ml})\end{array}$ & $\mathrm{RR}(95 \% \mathrm{CI})$ & Reference \\
\hline Breast & 24 & Prospective & 31,867 & High $v s$. low & $0.92(0.83-1.02)$ & 15 \\
\hline Breast & 11 & Case-control studies & & $<10$ vs. $>40$ & $\sim 5.4( \pm 4.4)$ & 13,16 \\
\hline \multirow[t]{2}{*}{ Breast } & 29 & Case-control studies & & High $v s$. low & $0.66(0.57-0.76)$ & 17 \\
\hline & 14 & Cohort studies & & High $v s$. low & $0.92(0.83-1.01)$ & 17 \\
\hline \multirow[t]{9}{*}{ Colorectal } & 17 & $<2$ Years of follow-up & 949 & Per 10 & $0.82(0.67-1.00)$ & 18 \\
\hline & & $\geq 2-5$ Years of follow-up & 1,493 & & $0.78(0.69-0.89)$ & \\
\hline & & $>5$ Years of follow-up & 3,077 & & $0.90(0.81-0.99)$ & \\
\hline & & US & 3,016 & & $0.84(0.79-0.90)$ & \\
\hline & & Outside US & 2,690 & & $0.91(0.81-1.01)$ & \\
\hline & & BMI $<25 \mathrm{~kg} / \mathrm{m}^{2}$ & 2,310 & & $0.83(0.77-0.90)$ & \\
\hline & & $\mathrm{BMI}>25 \mathrm{~kg} / \mathrm{m}^{2}$ & 3,293 & & $0.89(0.82-0.96)$ & \\
\hline & & Low physical activity & 1,472 & & $0.89(0.80-0.99)$ & \\
\hline & & High physical activity & 1,318 & & $0.81(0.73-0.90)$ & \\
\hline \multirow[t]{2}{*}{ Prostate } & 19 & Prospective & & High $v s$. low & $1.15(1.06-1.24)$ & 19 \\
\hline & & & & Per 10 & $1.04(1.02-1.06)$ & 19 \\
\hline
\end{tabular}

CI: Confidence interval; BMI: body mass index; RR: risk ratio.

\section{Pooled Analysis from Vitamin D Supplementation Studies}

Two articles reported pooled analyses of cancer incidence for women taking vitamin D supplements either in RCTs $(21$, 26) or voluntarily. In the first of those studies, involving 2,304 women, the hazard ratio (HR) for all-cancer incidence for $>40$ versus $<20 \mathrm{ng} / \mathrm{ml}$ was 0.33 [95\% confidence interval $(\mathrm{CI})=0.12-0.90](27)$. In the second study, involving 5,038 women, the rate ratio for breast cancer for those with $>60$ versus $<20 \mathrm{ng} / \mathrm{ml}$ was $0.18(p=0.02)(21)$.

On the basis of those studies, the serum 25(OH)D concentration for cancer prevention and treatment should be at least $40 \mathrm{ng} / \mathrm{ml}$. Few adverse effects occur for $25(\mathrm{OH}) \mathrm{D}$ concentrations below $100 \mathrm{ng} / \mathrm{ml}$. The observational studies that suggested adverse effects for $25(\mathrm{OH}) \mathrm{D}$ concentrations above about $60 \mathrm{ng} / \mathrm{ml}$ were largely determined to have enrolled some people who had begun vitamin D supplementation only shortly before entering the study and thus were put in the wrong $25(\mathrm{OH}) \mathrm{D}$ category $(28)$. A recent study of high-dose vitamin D supplementation showed that higher vitamin D doses, up to $10,000 \mathrm{IU} / \mathrm{d}$, reduced bone mass density slightly over a 3-year period but not bone strength at either the radius or tibia (29).

\section{Observational Studies of Cancer Survival or Mortality Rates}

A growing number of studies have examined survival or mortality rates versus $25(\mathrm{OH}) \mathrm{D}$ concentration for people with cancer. Such studies usually measure serum $25(\mathrm{OH}) \mathrm{D}$ concentration near the time of diagnosis and then monitor individuals for many years, looking at cancer-specific and overall survival or death rates. Inverse correlations between $25(\mathrm{OH}) \mathrm{D}$ concentration and cancer-specific survival have been found for several cancer types (see Tables III and IV).

\section{RCTs of Cancer Incidence}

RCTs are generally considered the strongest evidence regarding the efficacy and safety of a medical agent or procedure. However, vitamin $\mathrm{D}$ is a nutrient rather than a drug. Most vitamin D RCTs have been based on the guidelines for pharmaceutical drugs. The two basic assumptions for such trials are that the trial is the only source of the agent and that a linear dose-response relationship exists. Neither assumption is satisfied for vitamin D. Robert Heaney was the first to point out that RCTs for nutrients should be conducted differently for nutrients than for drugs (35). The most important consideration for vitamin D is that trials be based on $25(\mathrm{OH}) \mathrm{D}$ concentrations, not vitamin $\mathrm{D}$ dose, because all outcomes are related to $25(\mathrm{OH}) \mathrm{D}$ concentrations directly and vitamin $\mathrm{D}$ intake indirectly. The recommendations regarding vitamin $\mathrm{D}$ were recently extended: start with an understanding of the $25(\mathrm{OH}) \mathrm{D}$ concentration-health outcome relationship; measure baseline $25(\mathrm{OH}) \mathrm{D}$ concentrations and try to enroll those with values near the low end of the relationship; supplement with enough vitamin $\mathrm{D}_{3}$ to increase $25(\mathrm{OH}) \mathrm{D}$ concentrations to where the relationship no longer increases; measure achieved $25(\mathrm{OH}) \mathrm{D}$ concentration one or more times during the trial; base outcomes on $25(\mathrm{OH}) \mathrm{D}$ concentrations, not vitamin $\mathrm{D}_{3}$ dose (36). So many vitamin D RCTs have failed - not just for cancer but for many other health outcomes - because the 
Table II. Breast cancer incidence on the basis of 25-hydroxyvitamin D [25(OH)D] concentration from single prospective studies.

\begin{tabular}{|c|c|c|c|c|c|c|}
\hline Cohort & $\begin{array}{l}\text { Follow-up period } \\
\text { (years) }\end{array}$ & Conditions & $\begin{array}{c}\text { Cases/controls, } \\
\mathrm{n}\end{array}$ & $\begin{array}{c}25(\mathrm{OH}) \mathrm{D} \\
(\mathrm{ng} / \mathrm{ml})\end{array}$ & $\mathrm{RR}(95 \% \mathrm{CI}) *$ & Reference \\
\hline \multirow[t]{2}{*}{ Nurses' Health Study } & \multirow[t]{2}{*}{ Up to 10} & Winter blood draw & $712 / 703$ & $>32.7$ vs. $<17.5$ & $1.10(0.75-1.60)$ & 20 \\
\hline & & Summer blood draw & $783 / 799$ & $>32.7$ vs.$<17.5$ & $0.66(0.46-0.94)$ & 20 \\
\hline $\begin{array}{l}\text { Lappe RCTs, } \\
\text { Grassroots Health }\end{array}$ & Median 4.0 & & $77 / 4961$ & $>60$ vs. $<20$ & $0.29(0.05-0.82), p=0.03$ & 21 \\
\hline
\end{tabular}

CI: Confidence interval; ca/co: cases/controls; EPIC: European Prospective Investigation into Cancer and Nutrition; RCT: randomized controlled trial; RR: relative risk; SD: standard deviation. *Multivariate adjusted.

Table III. Survival after diagnosis of breast cancer with respect to serum 25-hydroxyvitamin D [25(OH)D] concentrations from a single prospective study (follow-up period of 8 years) (30).

\begin{tabular}{lcccc}
\hline Conditions & Cases/total, $\mathrm{n}$ & $25(\mathrm{OH}) \mathrm{D}(\mathrm{ng} / \mathrm{ml})$ & Cancer-specific survival & Overall survival \\
\hline All participants, fully adjusted & $88 / 1045$ & $>25.1$ vs. $<16.8$ & $\mathrm{RR}=0.85(95 \% \mathrm{CI}=0.55-1.33)$, & \\
Fully adjusted & $176 / 1045$ & $>25.1$ vs. $<16.8$ & $p_{\text {trend }}=0.53$ & $\mathrm{RR}=0.72(95 \% \mathrm{CI}=0.54-0.98)$, \\
$p_{\text {trend }}=0.03$ & \\
Premenopausal & & $>25.1$ vs. $<16.8$ & HR=0.37 (95\% CI=0.15-0.93) & HR=0.45 (95\% CI=0.21-0.96) \\
\hline
\end{tabular}

CI: Confidence interval; HR: hazard ratio; RR: risk ratio.

participants had relatively high baseline $25(\mathrm{OH}) \mathrm{D}$ concentrations and the vitamin $\mathrm{D}$ dose was too low to produce much change in health outcome.

Recently, the results of the VITamin D and OmegA-3 TriaL (VITAL) for cancer were published (37). Participants in the treatment arm were given 2,000 IU/d of vitamin $\mathrm{D}_{3}$ for a mean period of 5.3 years. Based on intention to treat the entire group, the HR for cancer incidence was $0.96(95 \% \mathrm{CI}=0.88-1.06)$ and for cancer death, 0.83 (95\% $\mathrm{CI}=0.67-1.02)$. However, in the secondary analyses, several significant reductions in cancer were apparent: For participants with body mass index (BMI) $<25 \mathrm{~kg} / \mathrm{m}^{2}, \mathrm{HR}=0.76$ (95\% CI=0.63-0.90); for Black people, $\mathrm{HR}=0.77$ (95\% CI=0.50-1.01); for cancer death, omitting the first year of data, $\mathrm{HR}=0.79$ (95\% $\mathrm{CI}=0.63-0.99)$. The trial had some limitations: The mean baseline $25(\mathrm{OH}) \mathrm{D}$ concentration for those who provided measurements was $31 \mathrm{ng} / \mathrm{ml}$. The vitamin D dose was limited to $2000 \mathrm{IU} / \mathrm{d}$. All participants were permitted to take $600-800 \mathrm{IU} / \mathrm{d}$ of vitamin D, and compliance was not $100 \%$. Given those limitations and strengths, the secondary analyses provide strong evidence that vitamin D reduces risk of both cancer incidence and death. A letter to the editor pointed out that the secondary analyses from that RCT as well as one on progression from prediabetes to diabetes mellitus should be accepted as demonstrating beneficial effects of vitamin D supplementation (38). The response letter did not disagree, but it pointed out that neither article gave any guidance on the matter (39). Secondary analyses may often be ignored because if results from enough subgroups are analyzed, some analyses are likely to report significant results. Here, both BMI and Black ethnicity are well known to affect serum $25(\mathrm{OH}) \mathrm{D}$ concentrations

\section{Mendelian Randomization (MR) Studies}

MR studies look at several alleles of genes that affect serum $25(\mathrm{OH}) \mathrm{D}$ concentrations to genetically predict concentrations in participants with or without the health outcome of interest. The genes of interest may include CYP24A1, CG, DHCR7, and $C P Y 2 R 1$. The alleles examined for those genes may affect 25(OH)D concentrations by about $1 \mathrm{ng} / \mathrm{ml}$ each (40). Because variations in alleles only affect the total $25(\mathrm{OH}) \mathrm{D}$ concentration by a small amount, many participants are generally used, up to 100,000 or more. Although in principle MR studies should provide reliable evidence regarding whether $25(\mathrm{OH}) \mathrm{D}$ concentration is causally linked to reduced risk of cancer, such findings have been reported only for allcancer mortality rate (41) and ovarian cancer incidence (40). An MR analysis using data from the UK Biobank for 438,870 White participants aged 36-73 years, including 46,155 cancer cases and 6998 cancer deaths, did not show a significant correlation between the predicted $25(\mathrm{OH}) \mathrm{D}$ concentration based on using five $25(\mathrm{OH}) \mathrm{D}$ genetic markers and either cancer incidence or mortality rate (42). However, for $76 \mathrm{MR}$ studies of cancer risk through October 31, 2017, a few 
Table IV. Survival after cancer diagnosis related to 25-hydroxyvitamin D [25(OH)D] concentration from meta-analyses.

\begin{tabular}{|c|c|c|c|c|c|}
\hline Cancer type & Cases/total, $\mathrm{n}^{*}$ & $25(\mathrm{OH}) \mathrm{D}(\mathrm{ng} / \mathrm{ml})$ & $\begin{array}{c}\text { Cancer-specific survival, } \\
\text { RR }(95 \% \mathrm{CI})\end{array}$ & $\begin{array}{l}\text { Overall survival, } \\
\text { RR }(95 \% \mathrm{CI})\end{array}$ & Reference \\
\hline Breast & $\begin{array}{l}194 / 2,636 \\
622 / 4,413\end{array}$ & High $v s$. low & $0.57(0.38-0.84)$ & $0.62(0.49-0.78)$ & 31 \\
\hline Breast & $1,024 / 9,984$ & High $v s$. low & Not given & $0.67(0.56-0.79)$ & 32 \\
\hline Colorectal & $\begin{array}{c}1,594 / 6,366 \\
2,330 / 10,718\end{array}$ & $\begin{array}{l}\text { High } v s \text {. low } \\
\text { High } v s \text {. low }\end{array}$ & $0.67(0.57-0.78)$ & $0.68(0.55-0.78)$ & 33 \\
\hline Prostate & No data/7,808 & Per 8 ng/ml & $0.91(0.87-0.97), p=0.02$ & $0.91(0.84-0.98), p=0.01$ & 34 \\
\hline
\end{tabular}

*Total: Which is more than in the low and high quantiles; CI: confidence interval; RR: risk ratio.

reported alcohol consumption, BMI, height, telomere length, and hormonal exposures as factors likely to contribute to cancer causation (43).

A major problem with MR studies is that genetic variations in $25(\mathrm{OH}) \mathrm{D}$ concentration are with respect to population mean concentrations. One recent study reported that a genetic risk score, derived using five single-nucleotide polymorphisms of vitamin $\mathrm{D}$ status, was associated with circulating $25(\mathrm{OH}) \mathrm{D}$ (mean \pm standard deviation $=27 \pm 10 \mathrm{ng} / \mathrm{ml} ; 23 \pm 17 \mathrm{ng} / \mathrm{ml}$ in the lowest versus $30 \pm 11 \mathrm{ng} / \mathrm{ml}$ in the highest quintile of genetic risk score) (44). Another article regarding breast and prostate cancer that failed to show a significant correlation between genetically determined variations in breast and prostate cancer with respect to $25(\mathrm{OH}) \mathrm{D}$ concentration admitted that nonlinear effects of vitamin D could not be excluded (45). As shown for breast cancer, risk changes more rapidly below $20 \mathrm{ng} / \mathrm{ml}$ than above $20 \mathrm{ng} / \mathrm{ml}$ (16). A recent article on the MR study stated (46): "Furthermore, the relationship between the 25(OH)D level and the risk of diseases may be nonlinear. As shown by previous studies, vitamin D supplementation only shows treatment effects among individuals with baseline $25(\mathrm{OH}) \mathrm{D}$ levels of no more than $(12 \mathrm{ng} / \mathrm{ml})$. When all participants were analysed irrespective of their baseline $25(\mathrm{OH}) \mathrm{D}$ levels, there was no treatment effect. Thus, the effect of $25(\mathrm{OH}) \mathrm{D}$ on health outcomes may differ by baseline serum $25(\mathrm{OH}) \mathrm{D}$ level. Considering the potential divergent $25(\mathrm{OH}) \mathrm{D}$ levels of the UK population, it is possible that we missed the true association between $25(\mathrm{OH}) \mathrm{D}$ levels and diseases among individuals of certain 25(OH)D levels".

Another MR study published around the same time supported that statement. For the Copenhagen data sets, the $\mathrm{HR}$ for a $10-\mathrm{ng} / \mathrm{ml}$ increase in the MR genetically determined $25(\mathrm{OH}) \mathrm{D}$ concentration and cancer mortality rate was 0.97 (95\% CI=0.94-1.10; $p=0.06)$, whereas the HR for $10 \mathrm{ng} / \mathrm{ml}$ of serum $25(\mathrm{OH}) \mathrm{D}$ concentration was $0.93(95 \%$ $\mathrm{CI}=0.88-0.98)$ (47). However, the $\mathrm{HRs}$ for $25(\mathrm{OH}) \mathrm{D}$ quartiles $1-4$ were $1.00,0.86$ (95\% $\mathrm{CI}=0.78-0.94), 0.87$ (95\% $\mathrm{CI}=0.78-0.96)$, and 0.79 (95\% $\mathrm{CI}=0.71-0.89)$, respectively $\left(p_{\text {trend }}=9.7 \times 10^{-5}\right)$. Thus, MR studies should not be relied on to determine whether the role of vitamin $\mathrm{D}$ in cancer is causal.

\section{Mechanisms}

The mechanisms whereby vitamin D reduces risk of cancer incidence, progression, and metastasis are well known. What is known about these mechanisms is not reviewed here but several reviews on the topic are available $(6,48-52)$.

\section{Prostate Cancer}

A higher serum $25(\mathrm{OH}) \mathrm{D}$ concentration is associated with increased risk of prostate cancer incidence (19). High solar UVB exposure is also linked to increased risk of prostate cancer incidence (11) and mortality (53). The U.S. geographical variation of prostate cancer mortality rate is different from that for most vitamin D-sensitive cancer types such as breast and colonic (8). That distribution was hypothesized to support the U-shaped $25(\mathrm{OH}) \mathrm{D}$ relationship for prostate cancer incidence (10) first reported by Tuohimaa et al. (9). In my opinion, the reason for increased risk of prostate cancer for higher $25(\mathrm{OH}) \mathrm{D}$ concentrations and UVB exposure is that vitamin D increases absorption of dietary calcium, and calcium is a risk factor for prostate cancer (54). A recent study reported that calcium intake was a significant risk factor for aggressive prostate cancer for African Americans (55). A preclinical study in France demonstrated that a diet high in calcium dose-dependently accelerated the progression of early-stage prostate tumors and that dietary vitamin D prevented this effect (56).

\section{Vitamin D Treatment of Patients With Cancer}

Because higher solar UVB doses and 25(OH)D concentrations are generally associated with better cancer survival rates and lower cancer mortality rates, one could expect that vitamin D supplementation would reduce risk of 
Table V. Update on "Vitamin D and Cancer Risk and Mortality: State of the Science, Gaps, and Challenges" (63).

\begin{tabular}{|c|c|c|}
\hline Problem & Current understanding & Reference \\
\hline $\begin{array}{l}\text { Link between } 25(\mathrm{OH}) \mathrm{D} \text { and breast cancer } \\
\text { is complex and not resolved. }\end{array}$ & $\begin{array}{l}\text { Because breast cancer can develop rapidly, case-control } \\
\text { studies provide better information than do prospective studies. }\end{array}$ & 13 \\
\hline $\begin{array}{l}25(\mathrm{OH}) \mathrm{D} \text { concentration has both positive } \\
\text { and negative relationships with prostate cancer. }\end{array}$ & $\begin{array}{l}\text { Increased calcium absorption seems to explain the reason for the } \\
\text { direct correlation between } 25(\mathrm{OH}) \mathrm{D} \text { and prostate cancer incidence. }\end{array}$ & 55 \\
\hline $\begin{array}{l}\text { Observational studies of incidence of several } \\
\text { other cancers do not show reduced incidence } \\
\text { with higher } 25(\mathrm{OH}) \mathrm{D} \text {. }\end{array}$ & $\begin{array}{l}\text { Because ecological studies in single midlatitude countries } \\
\text { report similar inverse correlations between solar UVB doses } \\
\text { and cancer incidence, and because most types of cancer are epithelial, } \\
\text { the most likely explanation is that observational studies were affected } \\
\text { by changes in serum 25(OH)D with long follow-up times. }\end{array}$ & 22,13 \\
\hline \multirow[t]{2}{*}{$\begin{array}{l}\text { Supplementation trials have not supported } \\
\text { the role of vitamin D in reducing cancer risk. }\end{array}$} & $\begin{array}{l}\text { The VITAL study showed that } 2000 \mathrm{IU} / \mathrm{d} \text { of vitamin } \mathrm{D}_{3} \text { can reduce } \\
\text { cancer incidence and death for selected subpopulations. }\end{array}$ & 37,38 \\
\hline & $\begin{array}{l}\text { Pooled results from studies including women taking vitamin } \mathrm{D}_{3} \\
\text { supplements have shown that raising } 25(\mathrm{OH}) \mathrm{D} \text { to above } 60 \mathrm{ng} / \mathrm{ml} \\
\text { significantly reduces risk of all-cancer and breast cancer incidence rates. }\end{array}$ & 21,27 \\
\hline $\begin{array}{l}\text { Mendelian randomization studies do not support } \\
\text { a role of vitamin D in reducing cancer risk. }\end{array}$ & $\begin{array}{l}\text { Mendelian randomization studies are sensitive to small } 25(\mathrm{OH}) \mathrm{D} \\
\text { variations near the mean of the population studied. They are not } \\
\text { sensitive to low and high concentrations, as in observational studies. }\end{array}$ & 47 \\
\hline $\begin{array}{l}\text { Of the relatively few investigations of } \\
\text { vitamin D biochemical status and cancer risk } \\
\text { in Black populations, most have been } \\
\text { retrospective case-control analyses, making } \\
\text { their interpretation challenging because of } \\
\text { issues related to reverse causality. }\end{array}$ & $\begin{array}{l}\text { As discussed here, reverse causality is an assumption not } \\
\text { proven to apply to case-control analyses regarding } 25(\mathrm{OH}) \mathrm{D} \\
\text { concentration and cancer incidence. }\end{array}$ & \\
\hline
\end{tabular}

cancer death. That appears to be the case. A study in Ireland reported that for 5,417 women aged 50-80 years diagnosed with breast cancer during 2001-2011 and monitored for up to 11 years, the 2,581 who started taking vitamin D supplements after breast cancer diagnosis had a $20 \%$ reduced risk of cancer-specific mortality $(\mathrm{HR}=0.80,95 \% \mathrm{CI}=0.64$ $0.99 ; p=0.048)(57)$. For those who started taking vitamin D supplements within 6 months of diagnosis, the reduction increased to $49 \%(\mathrm{HR}=0.51,95 \% \mathrm{CI}=0.34-0.74 ; p<0.001)$.

A meta-analysis of 12 RCTs with 428 cancer deaths out of 22,793 participants in the vitamin D treatment arms and 511 cancer deaths out of 22,785 controls reported the risk ratio for death in the treatment arm of 0.84 (95\% $\mathrm{CI}=0.74-0.95)(58)$.

\section{Hill's Criteria for Causality}

A. Bradford Hill outlined the criteria for causality in a biological system in his 1965 address to the British Medical Society (59). The criteria applicable to vitamin D and cancer include strength of association, consistency of observations, temporality (exposure must precede outcome), biological gradient, plausibility, coherence with known facts, experiment (e.g. RCT), and analogy. Later, "other scientific considerations include study designs, statistical tests, bias, confounding, and measurement issues" were added (60). Two articles reviewed the evidence for causality for UVB exposure/vitamin D and reduced risk of cancer on the basis of the original Hill criteria $(61,62)$. Both concluded that all relevant criteria were satisfied except perhaps experimental verification. That criterion has now been satisfied with the secondary analyses of results of the VITAL study $(37,38)$ as well as the open-label vitamin D studies of all-cancer (27) and breast cancer (21) incidence, for which the higher $25(\mathrm{OH}) \mathrm{D}$ concentrations were largely the result of vitamin D supplementation. In addition, support for the other criteria have been strengthened on the basis of more recent studies, such as those discussed here.

An article was published in 2017 with the title "Vitamin D and Cancer Risk and Mortality: State of the Science, Gaps, and Challenges" (63). The problems those authors identified together with newer information are summarized in Table V. Better understandings now exist, based on articles they overlooked or that were published later.

\section{Summary and Conclusion}

This review describes results from ecological studies of UVB dose and cancer risk, observational studies of $25(\mathrm{OH}) \mathrm{D}$ concentrations and UVB exposure and cancer risk, open-label vitamin D supplementation studies of cancer risk, observational studies of survival after cancer with respect to baseline $25(\mathrm{OH}) \mathrm{D}$ concentrations, RCTs of vitamin D 
supplementation and cancer risk, MR studies, and vitamin D treatment of cancer. Overall, UVB exposure and higher $25(\mathrm{OH}) \mathrm{D}$ concentrations are associated with reduced risk of cancer incidence and mortality, with few exceptions. Although RCTs are generally regarded in medical circles as being required to prove effectiveness and lack of important adverse effects for any treatment, RCTs with vitamin D are difficult to conduct, and most have been poorly designed and carried out. Nonetheless, the VITAL study reported significantly reduced risk of all-cancer incidence and mortality rates in secondary analyses. Scientifically, Hill's criteria for causality in a biological system are more appropriate, and two analyses using Hill's criteria published before the VITAL study results reported that those criteria were largely satisfied. This article also showed why MR studies are inappropriate for examining the causal role of vitamin $\mathrm{D}$ in reducing cancer risk. On the basis of those findings, medical practice should embrace and public health advice should encourage use of vitamin D to reduce cancer risk and increase survival rates after diagnosis.

\section{Conflicts of Interest}

The Author received funding from Bio-Tech Pharmacal, Inc. (Fayetteville, AR, USA).

\section{References}

1 Garland CF and Garland FC: Do sunlight and vitamin D reduce the likelihood of colon cancer? Int J Epidemiol 9(3): 227-231, 1980. PMID: 7440046. DOI: 10.1093/ije/9.3.227

2 Grant WB: An estimate of premature cancer mortality in the U.S. Due to inadequate doses of solar ultraviolet-b radiation. Cancer 94(6): 1867-1875, 2002. PMID: 11920550. DOI: $10.1002 /$ cncr. 10427

3 Grant WB and Garland CF: The association of solar ultraviolet B (UVB) with reducing risk of cancer: Multifactorial ecologic analysis of geographic variation in age-adjusted cancer mortality rates. Anticancer Res 26(4A): 2687-2699, 2006. PMID: 16886679 .

4 Tran B, Jordan SJ, Lucas R, Webb PM and Neale R: Association between ambient ultraviolet radiation and risk of epithelial ovarian cancer. Cancer Prev Res 5(11): 1330-1336, 2012. PMID: 23034146. DOI: 10.1158/1940-6207.CAPR-12-0279

5 De Stefani E, Boffetta P, Deneo-Pellegrini H, Ronco AL, Aune D, Acosta G, Brennan P, Mendilaharsu M and Ferro G: Meat intake, meat mutagens and risk of lung cancer in Uruguayan men. Cancer Causes Control 20(9): 1635-1643, 2009. PMID: 19685149. DOI: $10.1007 / \mathrm{s} 10552-009-9411-2$

6 Moukayed M and Grant WB: Molecular link between vitamin D and cancer prevention. Nutrients 5(10): 3993-4021, 2013. PMID: 3820056. DOI: $10.3390 /$ nu5103993

7 Grant WB: Re: Prospective study of ultraviolet radiation exposure and risk of breast cancer in the United States. Environ Res 152: 517-518, 2017. PMID: 27751444. DOI: 10.1016/ j.envres.2016.09.011

8 National Institute of Health: Atlas of Cancer Mortality in the United States, 1950-1994 (1999).
9 Tuohimaa P, Tenkanen L, Ahonen M, Lumme S, Jellum E, Hallmans G, Stattin P, Harvei S, Hakulinen T, Luostarinen T, Dillner J, Lehtinen M and Hakama M: Both high and low levels of blood vitamin $\mathrm{d}$ are associated with a higher prostate cancer risk: A longitudinal, nested case-control study in the Nordic countries. Int J Cancer 108(1): 104-108, 2004. PMID: 14618623. DOI: $10.1002 / \mathrm{ijc} .11375$

10 Grant WB: Geographic variation of prostate cancer mortality rates in the United States: Implications for prostate cancer risk related to vitamin D. Int J Cancer 111(3): 470-471; author reply 472, 2004. PMID: 15221981. DOI: $10.1002 / \mathrm{ijc} .20220$

11 Nair-Shalliker V, Smith DP, Egger S, Hughes AM, Kaldor JM, Clements M, Kricker A and Armstrong BK: Sun exposure may increase risk of prostate cancer in the high UV environment of New South Wales, Australia: A case-control study. Int J Cancer 131(5): E726-732, 2012. PMID: 22173996. DOI: 10.1002/ijc.27400

12 Oh EY, Ansell C, Nawaz H, Yang CH, Wood PA and Hrushesky WJ: Global breast cancer seasonality. Breast Cancer Res Treat 123(1): 233-243, 2010. PMID: 20130986. DOI: 10.1007/s10549009-0676-7

13 Grant WB: 25-hydroxyvitamin d and breast cancer, colorectal cancer, and colorectal adenomas: Case-control versus nested case-control studies. Anticancer Res 35(2): 1153-1160, 2015. PMID: 25667506.

14 Grant WB: Effect of follow-up time on the relation between prediagnostic serum 25-hydroxyvitamin $\mathrm{D}$ and all-cause mortality rate. Dermatoendocrinol 4(2): 198-202, 2012. PMID: 3427200. DOI: $10.4161 /$ derm.20514

15 Kim Y and Je Y: Vitamin D intake, blood 25(OH)D levels, and breast cancer risk or mortality: A meta-analysis. Br J Cancer 110(11): 2772-2784, 2014. PMID: 24714744. DOI: 10.1038/bjc.2014.175

16 Grant WB and Boucher BJ: Randomized controlled trials of vitamin D and cancer incidence: A modeling study. PLoS One 12(5): e0176448, 2017. DOI: 10.1371/journal.pone.0176448

17 Estebanez N, Gomez-Acebo I, Palazuelos C, Llorca J and Dierssen-Sotos T: Vitamin D exposure and risk of breast cancer: A meta-analysis. Sci Rep 8(1): 9039, 2018. PMID: 29899554. DOI: 10.1038/s41598-018-27297-1

18 McCullough ML, Zoltick ES, Weinstein SJ, Fedirko V, Wang M, Cook NR, Eliassen AH, Zeleniuch-Jacquotte A, Agnoli C, Albanes D, Barnett MJ, Buring JE, Campbell PT, Clendenen TV, Freedman ND, Gapstur SM, Giovannucci EL, Goodman GG, Haiman CA, Ho GYF, Horst RL, Hou T, Huang WY, Jenab M, Jones ME, Joshu CE, Krogh V, Lee IM, Lee JE, Mannisto S, Le Marchand L, Mondul AM, Neuhouser ML, Platz EA, Purdue MP, Riboli E, Robsahm TE, Rohan TE, Sasazuki S, Schoemaker MJ, Sieri S, Stampfer MJ, Swerdlow AJ, Thomson CA, Tretli S, Tsugane S, Ursin G, Visvanathan K, White KK, Wu K, Yaun SS, Zhang X, Willett WC, Gail MH, Ziegler RG and Smith-Warner SA: Circulating vitamin d and colorectal cancer risk: An international pooling project of 17 cohorts. J Natl Cancer Inst 111(2): 158-169, 2019. PMID: 29912394. DOI: 10.1093/jnci/djy087

19 Gao J, Wei W, Wang G, Zhou H, Fu Y and Liu N: Circulating vitamin $\mathrm{D}$ concentration and risk of prostate cancer: A doseresponse meta-analysis of prospective studies. Ther Clin Risk Manag 14: 95-104, 2018. PMID: 29386901. DOI: 10.2147/TCRM.S149325

20 Eliassen AH, Warner ET, Rosner B, Collins LC, Beck AH, Quintana LM, Tamimi RM and Hankinson SE: Plasma 25- 
hydroxyvitamin D and risk of breast cancer in women followed over 20 years. Cancer Res 76(18): 5423-5430, 2016. PMID: 5026605. DOI: 10.1158/0008-5472.CAN-16-0353

21 McDonnell SL, Baggerly CA, French CB, Baggerly LL, Garland CF, Gorham ED, Hollis BW, Trump DL and Lappe JM: Breast cancer risk markedly lower with serum 25-hydroxyvitamin d concentrations $\geq 60$ vs. $<20 \mathrm{ng} / \mathrm{ml}(150$ vs. $50 \mathrm{nmol} / \mathrm{l})$ : Pooled analysis of two randomized trials and a prospective cohort. PLoS One 13(6): e0199265, 2018. PMID: 6003691. DOI: 10.1371/ journal.pone. 0199265

22 Grant WB: Effect of interval between serum draw and followup period on relative risk of cancer incidence with respect to 25hydroxyvitamin D level: Implications for meta-analyses and setting vitamin D guidelines. Dermatoendocrinol 3(3): 199-204, 2011. PMID: 3219171. DOI: 10.4161/derm.3.3.15364

23 Haugen J, Chandyo RK, Ulak M, Mathisen M, Basnet S, Brokstad KA, Valentiner-Branth P, Shrestha PS and Strand TA: 25-Hydroxy-vitamin D concentration is not affected by severe or non-severe pneumonia, or inflammation, in young children. Nutrients 9(1): 52, 2017. PMID: 28106720. DOI: 10.3390/ nu9010052

24 Kim HB, Myung SK, Lee YJ, Park BJ and Korean MetaAnalysis Study Group: Efficacy of vitamin D supplementation in combination with conventional antiviral therapy in patients with chronic hepatitis $\mathrm{C}$ infection: A meta-analysis of randomised controlled trials. J Hum Nutr Diet 31(2): 168-177, 2018. PMID: 28833855. DOI: 10.1111/jhn.12503

25 Savoie MB, Paciorek A, Zhang L, Van Blarigan EL, Sommovilla N, Abrams D, Atreya CE, Bergsland EK, Chern H, Kelley RK, Ko A, Laffan A, Sarin A, Varma MG, Venook AP and Van Loon $\mathrm{K}$ : Vitamin D levels in patients with colorectal cancer before and after treatment initiation. J Gastrointest Cancer, 2018. PMID: 30058032. DOI: 10.1007/s12029-018-0147-7

26 Lappe JM, Travers-Gustafson D, Davies KM, Recker RR and Heaney RP: Vitamin D and calcium supplementation reduces cancer risk: Results of a randomized trial. Am J Clin Nutr 85(6): 1586-1591, 2007. PMID: 17556697. DOI: 85/6/1586

27 McDonnell SL, Baggerly C, French CB, Baggerly LL, Garland CF, Gorham ED, Lappe JM and Heaney RP: Serum 25hydroxyvitamin D concentrations $\geq 40 \mathrm{ng} / \mathrm{ml}$ are associated with $>65 \%$ lower cancer risk: Pooled analysis of randomized trial and prospective cohort study. PLoS One 11(4): e0152441, 2016. PMID: 4822815. DOI: 10.1371/journal.pone.0152441

28 Grant WB, Karras SN, Bischoff-Ferrari HA, Annweiler C, Boucher BJ, Juzeniene A, Garland CF and Holick MF: Do studies reporting ' $U$ '-shaped serum 25-hydroxyvitamin D health outcome relationships reflect adverse effects? Dermatoendocrinol 8(1): e1187349, 2016. PMID: 4951179. DOI: 10.1080/19381980.2016.1187349

29 Burt LA, Billington EO, Rose MS, Raymond DA, Hanley DA and Boyd SK: Effect of high-dose vitamin D supplementation on volumetric bone density and bone strength: A randomized clinical trial. JAMA 322(8): 736-745, 2019. PMID: 31454046. DOI: $10.1001 /$ jama.2019.11889

30 Yao S, Kwan ML, Ergas IJ, Roh JM, Cheng TD, Hong CC, McCann SE, Tang L, Davis W, Liu S, Quesenberry CP, Jr., Lee MM, Ambrosone CB and Kushi LH: Association of serum level of vitamin $\mathrm{D}$ at diagnosis with breast cancer survival: A case-cohort analysis in the pathways study. JAMA Oncol 3(3): 351-357, 2017. PMID: 27832250. DOI: 10.1001/jamaoncol.2016.4188
31 Maalmi H, Ordonez-Mena JM, Schottker B and Brenner H: Serum 25-hydroxyvitamin d levels and survival in colorectal and breast cancer patients: Systematic review and meta-analysis of prospective cohort studies. Eur J Cancer 50(8): 1510-1521, 2014. PMID: 24582912. DOI: 10.1016/j.ejca.2014.02.006

$32 \mathrm{Hu} \mathrm{K}$, Callen DF, Li J and Zheng H: Circulating vitamin d and overall survival in breast cancer patients: A dose-response metaanalysis of cohort studies. Integr Cancer Ther 17(2): 217-225, 2018. PMID: 28589744. DOI: 10.1177/1534735417712007

33 Maalmi H, Walter V, Jansen L, Boakye D, Schottker B, Hoffmeister $\mathrm{M}$ and Brenner H: Association between blood 25hydroxyvitamin D levels and survival in colorectal cancer patients: An updated systematic review and meta-analysis. Nutrients 10(7): pii: E896, 2018. PMID: 6073902. DOI: 10.3390/nu10070896

34 Song ZY, Yao Q, Zhuo Z, Ma Z and Chen G: Circulating vitamin d level and mortality in prostate cancer patients: A doseresponse meta-analysis. Endocr Connect 7(12): R294-R303, 2018. PMID: 6240137. DOI: 10.1530/EC-18-0283

35 Heaney RP: Guidelines for optimizing design and analysis of clinical studies of nutrient effects. Nutr Rev 72(1): 48-54, 2014. PMID: 24330136. DOI: 10.1111/nure.12090

36 Grant WB, Boucher BJ, Bhattoa HP and Lahore H: Why vitamin $\mathrm{D}$ clinical trials should be based on 25-hydroxyvitamin D concentrations. J Steroid Biochem Mol Biol 177: 266-269, 2018. PMID: 28842142. DOI: 10.1016/j.jsbmb.2017.08.009

37 Manson JE, Cook NR, Lee IM, Christen W, Bassuk SS, Mora S, Gibson H, Gordon D, Copeland T, D'Agostino D, Friedenberg G, Ridge C, Bubes V, Giovannucci EL, Willett WC and Buring JE: Vitamin D supplements and prevention of cancer and cardiovascular disease. N Engl J Med 380(1): 33-44, 2019. PMID: 30415629. DOI: 10.1056/NEJMoa1809944

38 Grant WB and Boucher BJ: Why secondary analyses in vitamin D clinical trials are important and how to improve vitamin D clinical trial outcome analyses - a comment on "extra-skeletal effects of vitamin D, nutrients 2019, 11, 1460". Nutrients 11(9): pii: E2182, 2019. PMID: 31514355. DOI: 10.3390/nu11092182

39 Misra M and Marino R: Reply to "why secondary analyses in vitamin D clinical trials are important and how to improve vitamin D clinical trial outcome analyses - a comment on "extra-skeletal effects of vitamin D", nutrients 2019, 11, 1460". Nutrients 11(9), 2019. PMID: 31514394. DOI: 10.3390/nu11092188

40 Ong JS, Cuellar-Partida G, Lu Y, Fasching PA, Hein A, Burghaus S, Beckmann MW, Lambrechts D, Van Nieuwenhuysen E, Vergote I, Vanderstichele A, Anne Doherty J, Anne Rossing M, Chang-Claude J, Eilber U, Rudolph A, Wang-Gohrke S, Goodman MT, Bogdanova N, Dork T, Durst M, Hillemanns P, Runnebaum IB, Antonenkova N, Butzow R, Leminen A, Nevanlinna H, Pelttari LM, Edwards RP, Kelley JL, Modugno F, Moysich KB, Ness RB, Cannioto R, Hogdall E, Hogdall CK, Jensen A, Giles GG, Bruinsma F, Kjaer SK, Hildebrandt MA, Liang D, Lu KH, Wu X, Bisogna M, Dao F, Levine DA, Cramer DW, Terry KL, Tworoger SS, Stampfer M, Missmer S, Bjorge L, Salvesen HB, Kopperud RK, Bischof K, Aben KK, Kiemeney LA, Massuger LF, Brooks-Wilson A, Olson SH, McGuire V, Rothstein JH, Sieh W, Whittemore AS, Cook LS, Le ND, Gilks CB, Gronwald J, Jakubowska A, Lubinski J, Kluz T, Song H, Tyrer JP, Wentzensen N, Brinton L, Trabert B, Lissowska J, McLaughlin JR, Narod SA, Phelan C, Anton-Culver H, Ziogas A, Eccles D, Campbell I, Gayther SA, Gentry-Maharaj A, Menon U, Ramus SJ, Wu AH, Dansonka-Mieszkowska A, Kupryjanczyk 
J, Timorek A, Szafron L, Cunningham JM, Fridley BL, Winham SJ, Bandera EV, Poole EM, Morgan TK, Risch HA, Goode EL, Schildkraut JM, Pearce CL, Berchuck A, Pharoah PD, ChenevixTrench G, Gharahkhani P, Neale RE, Webb PM and MacGregor S: Association of vitamin D levels and risk of ovarian cancer: A mendelian randomization study. Int J Epidemiol 45(5): 16191630, 2016. PMID: 5100621. DOI: 10.1093/ije/dyw207

41 Afzal S, Brondum-Jacobsen P, Bojesen SE and Nordestgaard BG: Genetically low vitamin D concentrations and increased mortality: Mendelian randomisation analysis in three large cohorts. BMJ 349: g6330, 2014. PMID: 4238742. DOI: 10.1136/bmj.g6330

42 Ong JS, Gharahkhani P, An J, Law MH, Whiteman DC, Neale $\mathrm{RE}$ and MacGregor S: Vitamin D and overall cancer risk and cancer mortality: A Mendelian randomization study. Hum Mol Genet 27(24): 4315-4322, 2018. PMID: 30508204. DOI: $10.1093 / \mathrm{hmg} / \mathrm{ddy} 307$

43 Pierce BL, Kraft $\mathrm{P}$ and Zhang C: Mendelian randomization studies of cancer risk: A literature review. Curr Epidemiol Rep 5(2): 184-196, 2018. PMID: 30034993. DOI: 10.1007/s40471018-0144-1

44 Chandler PD, Tobias DK, Wang L, Smith-Warner SA, Chasman DI, Rose L, Giovannucci EL, Buring JE, Ridker PM, Cook NR, Manson JE and Sesso HD: Association between vitamin d genetic risk score and cancer risk in a large cohort of U.S. women. Nutrients 10(1): pii: E55, 2018. PMID: 29315215. DOI: 10.3390/nu10010055

45 Jiang X, Dimou NL, Al-Dabhani K, Lewis SJ, Martin RM, Haycock PC, Gunter MJ, Key TJ, Eeles RA, Muir K, Neal D, Giles GG, Giovannucci EL, Stampfer M, Pierce BL, Schildkraut JM, Warren Andersen S, Thompson D, Zheng W, Kraft P and Tsilidis KK: Circulating vitamin D concentrations and risk of breast and prostate cancer: A Mendelian randomization study. Int J Epidemiol 48(5): 1416-1424, 2018. PMID: 30597039. DOI: 10.1093/ije/dyy284

46 Meng X, Li X, Timofeeva MN, He Y, Spiliopoulou A, Wei WQ, Gifford A, Wu H, Varley T, Joshi P, Denny JC, Farrington SM, Zgaga L, Dunlop MG, McKeigue P, Campbell H and Theodoratou E: Phenome-wide Mendelian-randomization study of genetically determined vitamin D on multiple health outcomes using the uk biobank study. Int J Epidemiol 48(5): 1425-1434, 2019. PMID: 31518429 . DOI: $10.1093 / \mathrm{ije} / \mathrm{dyz} 182$

47 Huang T, Afzal S, Yu C, Guo Y, Bian Z, Yang L, Millwood IY, Walters RG, Chen Y, Chen N, Gao R, Chen J, Clarke R, Chen Z, Ellervik C, Nordestgaard BG, Lv J, Li L and China Kadoorie Biobank Collaborative G: Vitamin d and cause-specific vascular disease and mortality: A Mendelian randomisation study involving 99,012 Chinese and 106,911 European adults. BMC Med 17(1): 160, 2019. PMID: 31466528. DOI: 10.1186/s12916-019-1401-y

48 Feldman D, Krishnan AV, Swami S, Giovannucci E and Feldman $\mathrm{BJ}$ : The role of vitamin $\mathrm{D}$ in reducing cancer risk and progression. Nat Rev Cancer 14(5): 342-357, 2014. PMID: 24705652. DOI: $10.1038 / \mathrm{nrc} 3691$

49 Moukayed M and Grant WB: The roles of uvb and vitamin $d$ in reducing risk of cancer incidence and mortality: A review of the epidemiology, clinical trials, and mechanisms. Rev Endocr Metab Disord 18(2): 167-182, 2017. PMID: 28213657. DOI: 10.1007/s11154-017-9415-2

50 Liu W, Zhang L, Xu HJ, Li Y, Hu CM, Yang JY and Sun MY: The anti-inflammatory effects of vitamin D in tumorigenesis. Int J Mol
Sci 19(9): pii: E2736, 2018. PMID: 6164284. DOI: 10.3390/ijms 19092736

51 Ferrer-Mayorga G, Larriba MJ, Crespo P and Munoz A: Mechanisms of action of vitamin D in colon cancer. J Steroid Biochem Mol Biol 185: 1-6, 2019. PMID: 29981368. DOI: 10.1016/j.jsbmb.2018.07.002

52 Haidari F, Abiri B, Iravani M, Razavi SM and Vafa M: The effects of uvb and vitamin D on decreasing risk of colorectal cancer incidence and mortality: A review of the epidemiology, clinical trials, and mechanisms. Nutr Cancer 71(5): 709-717, 2019. PMID: 30588844. DOI: 10.1080/01635581.2018.1521444

53 Nair-Shalliker V, Clements M, Fenech M and Armstrong BK: Personal sun exposure and serum 25-hydroxy vitamin D concentrations. Photochem Photobiol 89(1): 208-214, 2013. PMID: 22780860. DOI: 10.1111/j.1751-1097.2012.01201.x

54 Giovannucci E, Rimm EB, Wolk A, Ascherio A, Stampfer MJ, Colditz GA and Willett WC: Calcium and fructose intake in relation to risk of prostate cancer. Cancer Res 58(3): 442-447, 1998. PMID: 9458087.

55 Batai K, Murphy AB, Ruden M, Newsome J, Shah E, Dixon MA, Jacobs ET, Hollowell CM, Ahaghotu C and Kittles RA: Race and BMI modify associations of calcium and vitamin D intake with prostate cancer. BMC Cancer 17(1): 64, 2017. PMID: 5248493. DOI: 10.1186/s12885-017-3060-8

56 Capiod T, Barry Delongchamps N, Pigat N, Souberbielle JC and Goffin V: Do dietary calcium and vitamin D matter in men with prostate cancer? Nat Rev Urol 15(7): 453-461, 2018. PMID: 29765146. DOI: 10.1038/s41585-018-0015-Z

57 Madden JM, Murphy L, Zgaga L and Bennett K: De novo vitamin D supplement use post-diagnosis is associated with breast cancer survival. Breast Cancer Res Treat 172(1): 179-190, 2018. PMID: 30039288. DOI: 10.1007/s10549-018-4896-6

58 Zhang Y, Fang F, Tang J, Jia L, Feng Y, Xu P and Faramand A: Association between vitamin D supplementation and mortality: Systematic review and meta-analysis. BMJ 366: 14673, 2019. PMID: 31405892. DOI: 10.1136/bmj.14673

59 Hill AB: The environment and disease: Association or causation? Proc R Soc Med 58: 295-300, 1965. PMID: 1898525.

60 Potischman $\mathrm{N}$ and Weed DL: Causal criteria in nutritional epidemiology. Am J Clin Nutr 69(6): 1309S-1314S, 1999. PMID: 10359231 DOI: 10.1093/ajcn/69.6.1309S

61 Grant WB: How strong is the evidence that solar ultraviolet $b$ and vitamin $d$ reduce the risk of cancer?: An examination using Hill's criteria for causality. Dermatoendocrinol 1(1): 17-24, 2009. PMID: 2715209. DOI: 10.4161/derm.1.1.7388

62 Mohr SB, Gorham ED, Alcaraz JE, Kane CI, Macera CA, Parsons JK, Wingard DL and Garland CF: Does the evidence for an inverse relationship between serum vitamin $d$ status and breast cancer risk satisfy the Hill criteria? Dermatoendocrinol 4(2): 152-157, 2012. PMID: 3427194. DOI: 10.4161/derm. 20449

63 Mondul AM, Weinstein SJ, Layne TM and Albanes D: Vitamin $\mathrm{D}$ and cancer risk and mortality: State of the science, gaps, and challenges. Epidemiol Rev 39(1): 28-48, 2017. PMID: 28486651. DOI: 10.1093/epirev/mxx005

Received October 2, 2019

Revised November 18, 2019

Accepted November 20, 2019 